\title{
Trichostatin A with adenovirus-mediated p53 gene transfer synergistically induces apoptosis in breast cancer cell line MDA-MB-231
}

\author{
SEI-ICHIRO NAKAJIMA ${ }^{1,3}$, HIROTO NIIZEKI $^{1,3}$, MITSUO TADA $^{2}$, KOJI NAKAGAWA ${ }^{4}$, \\ SATOSHI KONDO ${ }^{3}$, FUTOSHI OKADA ${ }^{5}$ and MASANOBU KOBAYASHI ${ }^{1,6}$ \\ ${ }^{1}$ Division of Cancer Biology, ${ }^{2}$ Division of Cancer-Related Genes, Institute for Genetic Medicine, \\ ${ }^{3}$ Department of Surgical Oncology, Graduate School of Medicine, ${ }^{4}$ Department of Pathophysiology and Therapeutics, \\ Faculty of Pharmaceutical Sciences, Hokkaido University; ${ }^{5}$ Department of Biomolecular Function, Graduate School \\ of Medical Science, Yamagata University; ${ }^{6}$ Health Sciences University of Hokkaido, Hokkaido 061-0293, Japan
}

Received October 24, 2008; Accepted February 3, 2009

DOI: $10.3892 /$ or_00000417

\begin{abstract}
Although the p53 anti-oncogene is an important target for gene therapy of cancer, some cancers are resistant to 553 gene transfer. For this reason, it is important to find effective drugs to enhance cytotoxic effects of p53 gene transfer. Recent reports demonstrated that some histone deacetylase inhibitors in combination with p53 gene therapy induced apoptosis in certain cancer cells more efficiently than p53 gene therapy alone. We investigated whether histone deacetylase inhibitor Trichostatin A (TSA), in combination with p53 gene transfer could synergistically induce apoptosis in the breast cancer cell line MDA-MB-231. Whereas the adenovirus-expressing p53 (Ad-p53) by itself at up to 100 multiplicity of infection (MOI) induced apoptosis at a low level, Ad-p53 in combination with TSA synergistically induced apoptosis at a higher level in MDA-MB-231 cells than TSA or Ad-p53 alone. However, the combination of Ad-p53 and TSA did not enhance the expressions of p53 or p53-induced genes that are involved in apoptosis, and synergistically reduced the mitochondrial membrane potential and enhanced caspase- 3 activity. These results suggest that TSA have synergistic effects on the induction of apoptosis in MDA-MB-231 cells when combined with p53 gene transfer.
\end{abstract}

\section{Introduction}

Mutations of p53 tumor suppressor gene are the most common genetic alterations observed in human cancers (1). It has been demonstrated that the re-expression of wild-type p53 in cancer

Correspondence to: Dr Masanobu Kobayashi, School of Nursing Services, Health Sciences University of Hokkaido, 1757 Kanazawa, Tobetsu-cho, Ishikarigun, Hokkaido 061-0293, Japan

E-mail: mkobaya@hoku-iryo-u.ac.jp

Key words: Trichostatin A, p53, apoptosis, breast cancer cells, in which the endogenous p53 gene is deleted or mutated, restores a non-tumorigenic phenotype by suppressing tumor growth and inducing apoptosis $(2,3)$. The clinical trial of p53 gene transfer to tumors is effective in $\sim 60 \%$ of patients (4). Nonetheless, several cancers are refractory to the apoptosis induction by p53 gene transfer (5). Therefore, it is much anticipated to find effective drugs for enhancing the cytotoxicity of p53 gene transfer, and presently radiotherapy and chemotherapy are clinically used in place of those drugs (6-9).

Trichostatin A (TSA), which has originally been identified as an anti-fungal drug (10), inhibits histone deacetylase activity. A number of reports demonstrated that TSA functioned as a specific inhibitor of the mammalian cell cycle and induced apoptotic cell death in a leukemia cell line and several colorectal carcinoma cell lines (11-13). Histone acetylation mediates transcription by facilitating the binding of transcription factors to nucleosomal DNA (14), which suggests that a histone deacetylase inhibitor could promote p53-dependent transcription of down-stream genes such as Bax and $\mathrm{p} 21^{\text {waf } 1 / \mathrm{Cip} 1}$ and then induce apoptosis more efficiently in combination with p53 gene transfer than p53 gene transfer alone. In fact, one of the histone deacetylase inhibitors has been reported to activate the $\mathrm{p} 21^{\mathrm{waf} 1 / \mathrm{Cip} 1}$ promoter (17). Furthermore, recent reports demonstrated that some histone deacetylase inhibitors could synergistically induce apoptosis in combination with p53 gene therapy, compared with p53 gene therapy alone (16).

In this study, we examined the effects of TSA in combination with p53 gene therapy on the induction of apoptosis in breast cancer cell line MDA-MB-231 and found that TSA treatment synergistically increased the apoptosis induced by p53 gene transfer in MDA-MB-231 cells.

\section{Materials and methods}

Cell lines. MDA-MB-231 (breast cancer cell line, ATCC HTB26), was kindly provided by Dr Hiroshi Ishikura, the First Department of Pathology, Hokkaido University 
Graduate School of Medicine) MDA-MB-231 cells were maintained in DMEM/F12 medium supplemented with $10 \%$ fetal calf serum (FCS; Filtron). The 293 cells (transformed human embryonic kidney cell line, ATCC CRL1573) were maintained in DMEM medium supplemented with $10 \%$ FCS.

Reagents. Trichostatin A (TSA) was purchased from Wako Pure Chemical Co., Ltd. (Tokyo, Japan). Stock solution of TSA was prepared by diluting TSA at $10 \mathrm{mM}$ with ethanol and then stocked at $-20^{\circ} \mathrm{C}$. An anti-p53 mouse monoclonal antibody was purchased from Transduction Laboratories (Lexington, KY). cDNA probes bcl-2 and GML (20) were kindly supplied by Dr Y. Tsujimoto (Osaka University Graduate School of Medicine) and Dr T. Tokino (Sapporo Medical School), respectively.

Treatment with adenoviral vectors. The construction of recombinant replication-deficient adenoviral vectors and the experimental conditions for infecting the cells with the recombinant adenovirus vectors have been described previously (17). Briefly, infection with Ad-p53 or Ad-Null was accomplished by incubating the cells with adenovirus vectors at various multiplicities of infection (MOIs) in DMEM or DMEM/F12 medium supplemented with $1 \%$ FCS. After 1-h incubation, DMEM or DMEM/F12 medium supplemented with $10 \%$ FCS with or without various concentrations of trichostatin A (TSA) was added.

Assays of cell death. Cell death was evaluated by a colorimetric MTS assay (Cell Titer 96 Aqueous Non-radioactive Cell Proliferation Assay; Promega; Madison, WI) according to the manufacturer's instruction. Briefly, $2 \times 10^{3}$ cells were placed in each well of 96-well plates, and infected with adenovirus vector (25-100 MOI) in the absence or presence of TSA $(0,250$ and $500 \mathrm{nM})$. After incubation for $48 \mathrm{~h}$, the plates were again incubated for $3 \mathrm{~h}$ after an addition of $20 \mu 1$ of MTS solution. Subsequently, the absorbance was measured at $490 \mathrm{~nm}$ with an ELIZA reader (Bio-Rad Model 550). To quantify the cell numbers, a standard curve was created by plating non-treated cells in triplicate wells at the following concentrations: $0,2,000,10,000,20,000$ and 50,000 cells/well.

Apoptosis was evaluated by FACS analysis using propidium iodide (PI) and Annexin-V-FITC (Boehringer Mannheim, Mannheim, Germany) staining according to the manufacturer's instruction. The cells were placed in the well of 6 -well plates $\left(2 \times 10^{5}\right.$ cells/well $)$ and infected with adenovirus vectors (MOI 25-100) in the absence or presence of TSA (250-500 nM). After $48 \mathrm{~h}$ post-infection, the cells were collected, washed twice with cold phosphatebuffered saline, and resuspended in $100 \mu 1$ of binding buffer containing $20 \mu \mathrm{g} / \mathrm{ml}$ PI and $20 \mu \mathrm{g} / \mathrm{ml}$ Annexin-V-FITC. After $15 \mathrm{~min}, 400 \mu \mathrm{l}$ of the binding buffer was added and FACS analysis was performed on FACScaliber flow cytometer (Becton-Dickinson, Mountain View, CA). Data analysis was done with CellQuest software. Apoptosis was also investigated by TUNEL staining with the use of an In Situ Cell Detection kit (Rosche Molecular Biochemicals, Manheim) according to the manufacturer's instruction.
Mitochondrial membrane potential and caspase activity. For evaluation of mitochondrial membrane potential, the cells $\left(5 \times 10^{5} / \mathrm{ml}\right)$ were incubated with chloromethyl Xarosamine (CMXRos) (Molecular Probes Inc., Eugene, OR) according to the method described by Macho et al (18). CMXRos (1 $\mathrm{mM}$ ) was prepared as a stock solution in dimethylsulfoxide (DMSO) and stored at $-20^{\circ} \mathrm{C}$. Caspase activity was evaluated with a CasPACE ${ }^{\mathrm{TM}}$ Assay System kit (Promega) according to the manufacturer's instruction.

Northern blot analysis. Northern blot analysis was performed by the method described previously (19). Total RNA (20 $\mu \mathrm{g})$ was separated by electrophoresis in $1.2 \%$ denaturing formaldehyde-agarose gels. The RNA was transferred to nylon membrane (Hybond $\mathrm{N}^{+}$, Amersham) overnight by capillary elution and UV cross-linked. After pre-hybridization of the blots for $1-2 \mathrm{~h}$ at $42^{\circ} \mathrm{C}$ in hybridization buffer, the membrane was hybridized overnight at $42^{\circ} \mathrm{C}$ with the cDNA probes for p53, p2 $1^{\text {Waf } 1 / \text { Cip } 1}$ and Bax. The probed membrane was then washed and exposed to radiographic film. cDNA fragments for $\mathrm{p} 21^{\text {Waf1/Cip } 1}$, Bax, PIG-3 (21), P53AIP1 (22) and PERP (23) were amplified by RT-PCR, cloned into a TA cloning vector, purified from the vector and then used as probes for Northern blot assay. PCR primers were as follows: p2 $1^{\text {Waf1/Cip1 }}$ forward, gttccttgtggagccggagc; reverse, ggtacaa gacagtgacaggtc; Bax forward, tttgcttcagggtttcatcc; reverse, ccatcttcttccagatggtga; PIG-3 forward, aaattcaccaaaggtgctgg; reverse, gttcttgttggcctccatgt; PERP forward, catcgccttcga catcatc; reverse, tcaaagtcgctggagaaac; p53AIP1 forward, gaatggcagggctcagacac; reverse, tcagatttggggatacagaagga.

Luciferase assay. Firefly-luciferase reporter contsructs, pG13 Py-luc, containing 13 copies of a p53 DNA-binding consensus sequence linked to a luciferase reporter gene (gift from Dr B. Vogelstein, Johns Hopkins University), and pMO3, Bax promoter-luciferase construct (gift from Dr M. Oren, Weizmann Institute, Israel) were used to test transcriptional activities of $\mathrm{p} 53$. The cells $\left(3 \times 10^{6}\right)$ were placed in each well of 6-well plates, and $1 \mu \mathrm{g}$ of the reporter construct and $20 \mathrm{ng}$ of Renila-luciferase vector pRL-CMV (Promega, Tokyo, Japan) were cotransfected to the cells by a lipofection method (Lipofectamine, Gibco-BRL). After transfection with the reporter construct, the cells were infected with Ad-p53 or Ad-Null at 25 MOI. After incubation with Ad-p53 or AdNull for $1 \mathrm{~h}$, TSA was added to the cultures. After incubation for $24 \mathrm{~h}$, cells were lysed with the use of Passive Lysis buffer (Promega). Then luciferase activities were measured with a Dual-Luciferase ${ }^{\mathrm{TM}}$ Reporter Assay System (Promega) according to the manufacturer's instruction.

Western blot analysis. Western blot analysis was performed according to the method described previously (24). Briefly, samples were electrophoresed under non-reducing conditions on $12 \%$ polyacrylamide gels in Tris-glycin running buffer and electrotransferred to a $0.45 \mu \mathrm{m}$ nitrocellulose membrane. The membrane was then blocked overnight at $4{ }^{\circ} \mathrm{C}$ in blocking buffer (5\% skim-milk in $1 \%$ Tween-phosphate-buffered saline) and probed with first antibodies for $1 \mathrm{~h}$. After being washed, the membrane was incubated with a peroxidaseconjugated goat anti-mouse IgG secondary antibody (Jackson 
A

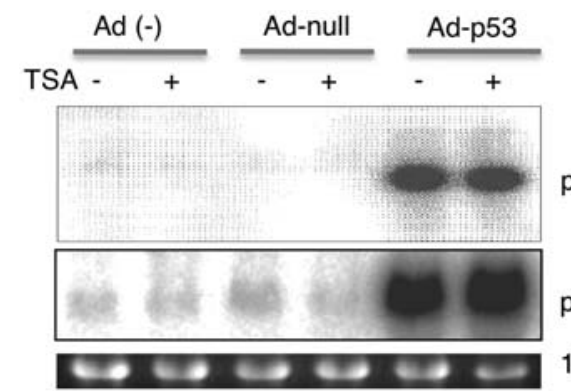

p53mRNA

p21mRNA

B

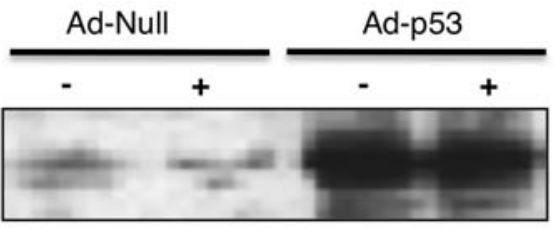

18S-rRNA

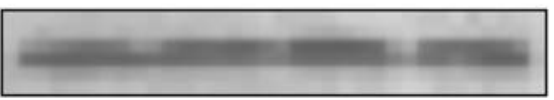

actin

C

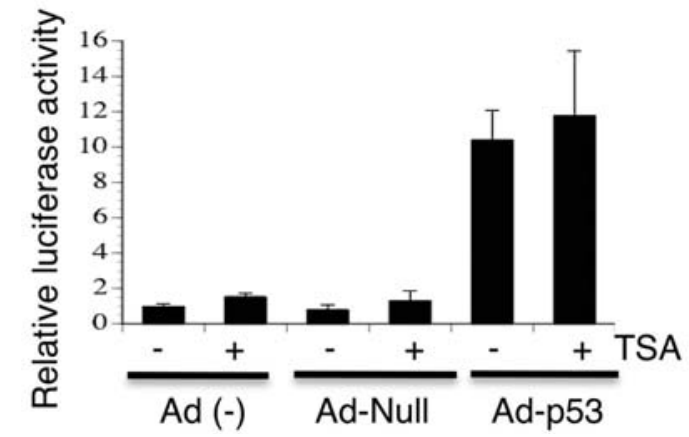

Figure 1. Expressions of p53 and p $21^{\text {Wafl/Cip1 } 1} \mathrm{mRNA}$ and $\mathrm{p} 53$ protein after the treatment with Ad-p53 or Ad-Null with or without TSA at $250 \mathrm{nM}$ in MDA-MB-231 cells. Data shown are the representative of three independent experiments. (A) Total RNAs were obtained $48 \mathrm{~h}$ after the treatment with Ad-p53 or Ad-Null at $25 \mathrm{MOI}$ in the presence or absence of $250 \mathrm{nM}$ TSA and then subjected to Northern blot analysis. (B) Cell lysates were obtained $48 \mathrm{~h}$ after the treatment with Ad-p53 or Ad-Null at $25 \mathrm{MOI}$ in the presence or absence of $250 \mathrm{nM}$ TSA and then subjected to Western blot analysis. (C) p53-dependent reporter activity of after the treatment with Ad-p53 or Ad-Null at $25 \mathrm{MOI}$ in the presence or absence of $250 \mathrm{nM}$ TSA. MDAMB-231 cells were transfected with pG13 Py-luc in combination with Renila-luciferase vector pRL-CMV, followed by the transfection with AdNull or Ad-p53 at 25 MOI and the treatment with or without TSA at $250 \mathrm{nM}$ for $48 \mathrm{~h}$ and then luciferase activities were measured. Data shown as relative luciferase activities compared with that in the cells without any treatment are representative of three independent experiments.

ImmunoResearch, PA, USA) and developed with the use of an ECL detection kit (Amersham, Tokyo, Japan).

\section{Results}

Expression of p53 mRNA and protein. Fig. 1A shows the p53 mRNA expression levels in MDA-MB-231 cells after the treatment with $\mathrm{p} 53$ gene transfer and/or TSA. Wild-type p53 mRNA expression was clearly induced by the infection with Ad-p53 at 25 MOI with or without TSA. TSA showed no additive effect on the p53 mRNA expression levels. The expression of $\mathrm{p} 21^{\text {wafl }} \mathrm{mRNA}$ was also induced by the infection with Ad-p53 at 25 MOI. Treatment with TSA only slightly showed an additive effect on the p21 mRNA expression induced by p53 gene transfer alone. Fig. 1B shows the p53 protein levels after the treatment with TSA alone, p53 gene

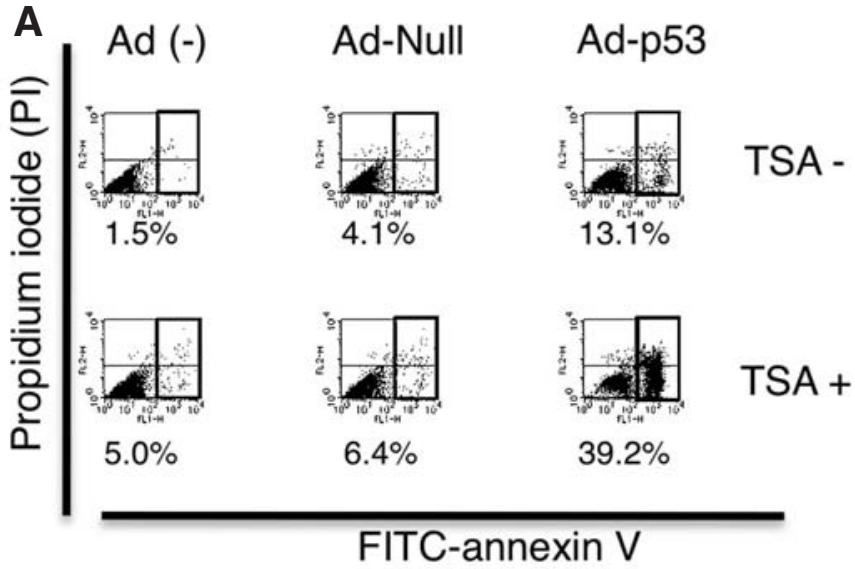

B
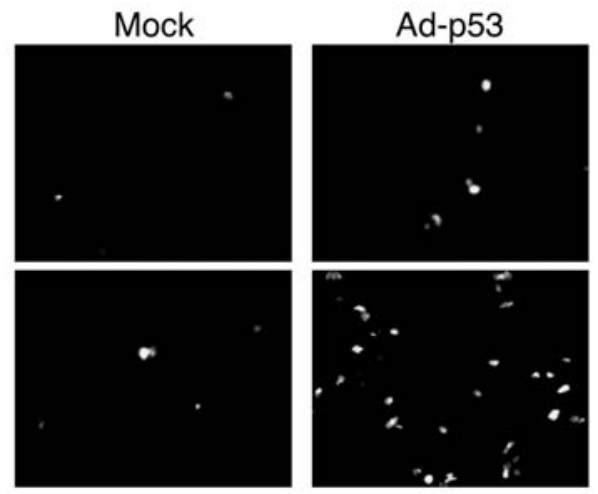

TSA

Ad-p53 + TSA

C

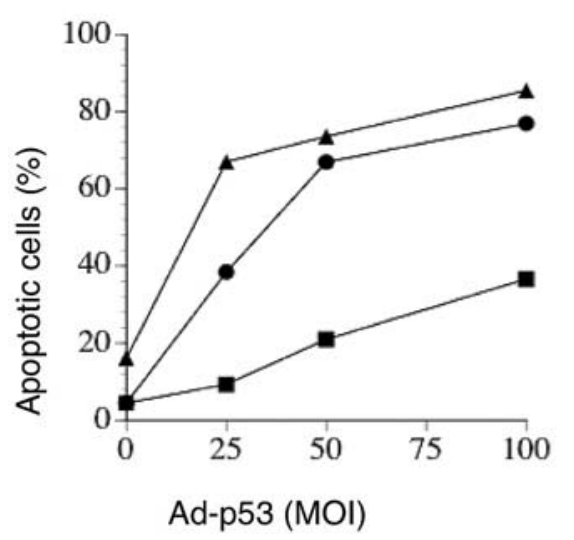

Figure 2. Apoptosis synergistically induced by the combination of TSA and p53 gene transfer. Data shown are representative data of three independent experiments. (A) Percentages of apoptotic cells after the treatment with Ad-Null or Ad-p53 at 25 MOI with or without $250 \mathrm{nM}$ of TSA were evaluated by FACS analysis. (B) TUNEL staining of the MDA-MB-231 cells treated with 25 MOI of Ad-p53 with or without $250 \mathrm{nM}$ of TSA. (C) Percentages of dead cells after treatment with Ad-p53 at 25 MOI with or without TSA at the concentrations indicated were evaluated by a colorimetric MTS assay. Each point indicates a mean of triplicate wells.

transfer alone and the combination of the two. Likewise, TSA showed no additive effect on the p53 protein expression levels. The reporter gene assay using pG13-Luc, which expresses the luciferase under the control of the p53responsive elements, showed that p53 gene transfer markedly stimulates the reporter activity and that TSA treatment slightly enhanced the reporter activity (Fig. 1C).

Cell death following treatment with p53 gene transfer and/or TSA. As shown in Fig. 2A, the combination of TSA and p53 
A

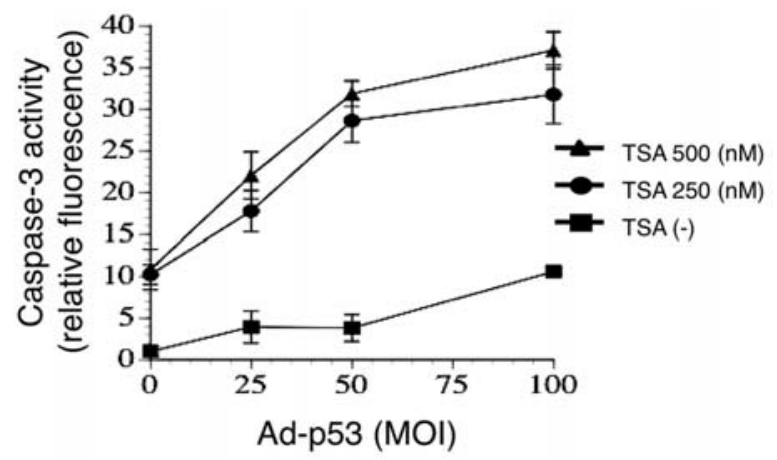

B

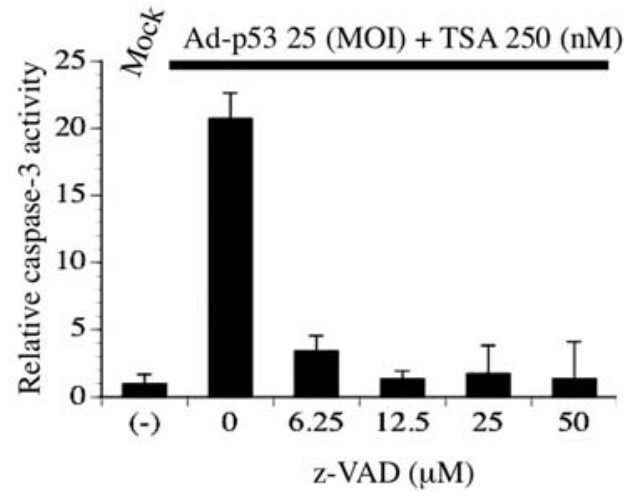

C

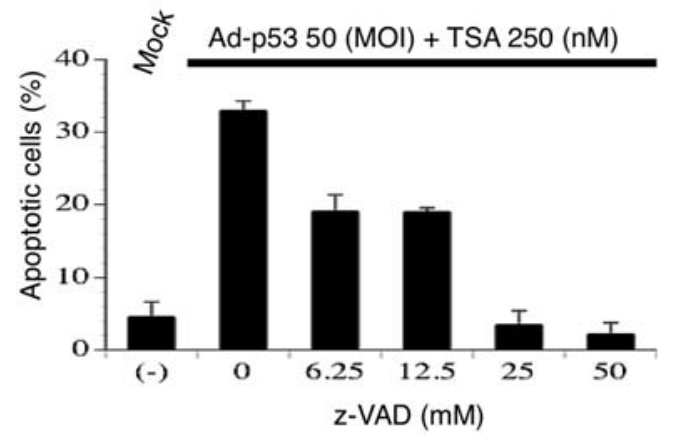

Figure 3. (A) Caspase-3 activity $48 \mathrm{~h}$ after the treatment with Ad-p53 and or TSA at the indicated concentrations in MDA-MB-231 cells. (B) Caspase-3 activity $48 \mathrm{~h}$ after the treatment with Ad-p53 at $25 \mathrm{MOI}$ and TSA at $250 \mathrm{nM}$ in MDA-MB-231 cells in the presence of a protease inhibitor, z-VAD. (C) Percentages of apoptotic cells $48 \mathrm{~h}$ after the treatment with Ad-p53 at 25 MOI and TSA at $250 \mathrm{nM}$ in MDA-MB-231 cells in the presence of z-VAD, determined by FACS analysis. Data shown are representative of three independent experiments.

induced apoptosis in $39.2 \%$, whereas p53 (25 MOI) alone and TSA $(250 \mathrm{nM})$ alone induced apoptosis in $13.1 \%$ and $5 \%$ of MDA-MB-231 cells, respectively. In order to confirm the results, we also examined the apoptosis with the use of a TUNEL staining method. Whereas a few MDA-MB-231 cells were positive for TUNEL staining when treated with TSA alone or p53 alone, a more number of the cells were positive for the staining after the treatment with the combination of TSA and p53 (Fig. 1B). We also examined the effects of the combination of TSA and p53 on cell viability by MTS assay. As shown in Fig. 1C, the cell death in MDA-MB-231 was induced synergistically by the combination of TSA and p53 gene transfer.

Caspase- 3 activity following treatment with p53 and/or TSA. Next, we examined the effect of the combination of TSA
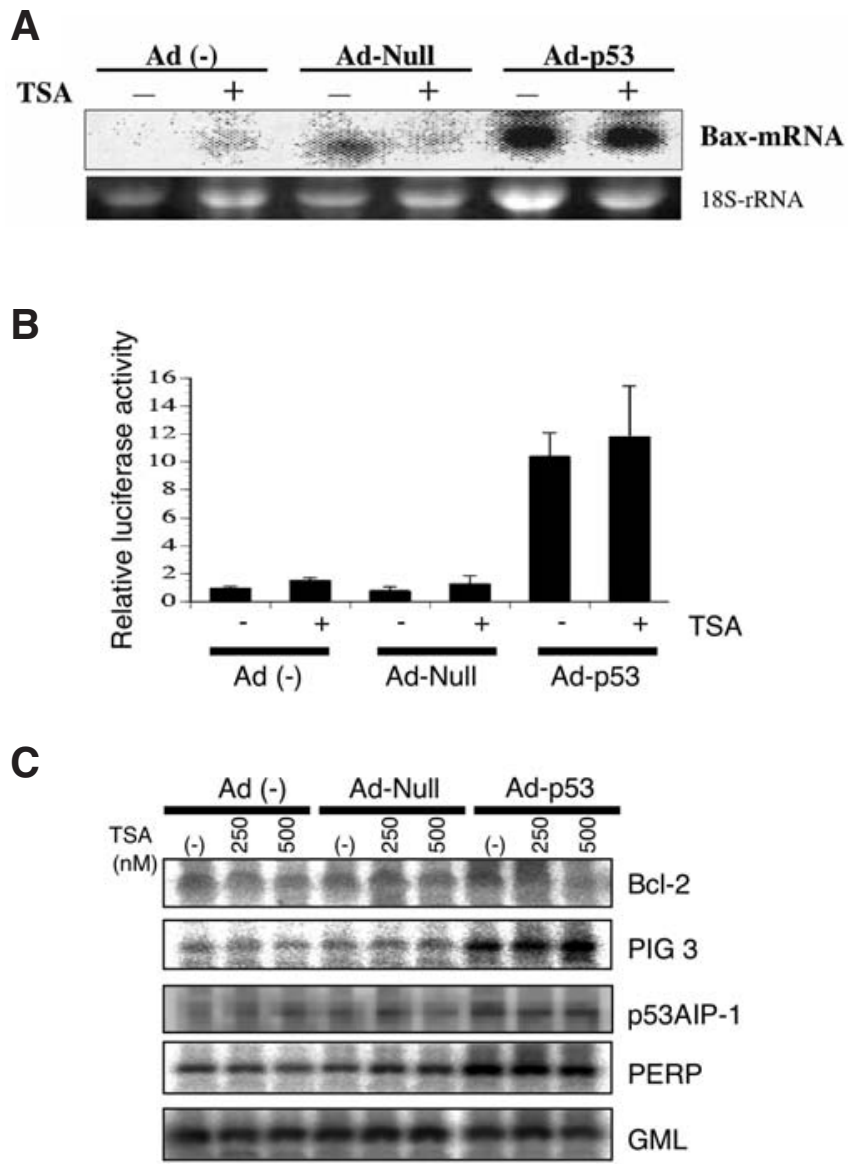

Figure 4. Expression of apoptosis related genes. (A) mRNA expression of Bax after the treatment with Ad-Null or Ad-p53 in the presence or absence of TSA in MDA-MB-231 cells. Total RNAs were obtained $48 \mathrm{~h}$ after the treatment with Ad-p53 or Ad-Null at $25 \mathrm{MOI}$ in the presence or absence of $250 \mathrm{nM}$ TSA and then subjected to Northern blot analysis. (B) The activity of Bax promoter after the treatment with Ad-p53 or Ad-Null at 25 MOI in the presence or absence of $250 \mathrm{nM}$ TSA. MDA-MB-231 cells were transfected with pMO3 in combination with Renila-luciferase vector pRL-CMV, followed by the transfection with Ad-Null or Ad-p53 at $25 \mathrm{MOI}$ and the treatment with or without TSA at $250 \mathrm{nM}$ for $48 \mathrm{~h}$ and then luciferase activities were measured. Data shown as relative luciferase activities compared with that in the cells without any treatment are the representative of three independent experiments. (C) Expression of bcl-2, PIG3, PERP and GML after the treatment with Ad-p53 with or without TSA.

and p53 on caspase activation. Fig. 3A shows caspase-3 activities after the treatment with p53 and/or TSA. p53 alone at up to $100 \mathrm{MOI}$ or TSA alone (250 and $500 \mathrm{nM}$ ) slightly activated caspase- 3 , whereas $\mathrm{p} 53$ in combination with TSA activated caspase- 3 synergistically in a dose-dependent manner. Reversely the caspase- 3 activation and apoptosis induced by the combination of p53 and TSA was inhibited by a protease-inhibitor, Z-VAD, in a dose-dependent manner (Fig. 3B and C).

Expression of apoptosis-related genes. Since it has been reported that Bax is involved in p53-induced apoptosis, we next examined whether Bax gene expression is modulated by the combination treatment of p53 gene transfer and TSA. Fig. 4A shows that the Bax mRNA expression was induced by the infection with Ad-p53 at 25 MOI. However, TSA did not enhance the Bax mRNA expression induced by p53 alone. Reporter gene assay also demonstrated that TSA did 
A

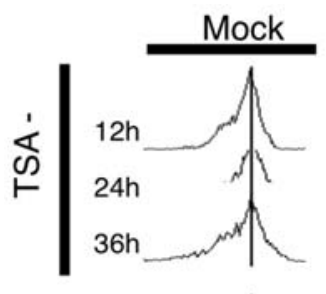

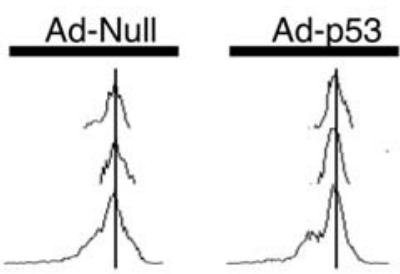

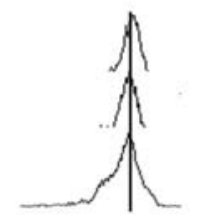

TSA
B

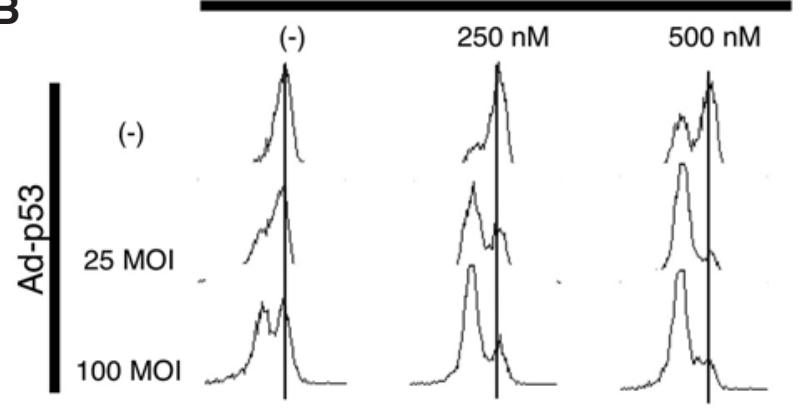

Figure 5. Mitochondrial membrane potential (delta psi $\mathrm{m}$ ) after the treatment with Ad-Null or Ad-p53 in the presence or absence of TSA in MDA-MB231 cells. (A) Time course of reduction of mitochondrial membrane potential after the treatment with Ad-p53 or Ad-Null at 25 MOI with or without TSA at $250 \mathrm{nM}$. (B) Dose-dependent effects of Ad-p53 and/or TSA on the reduction of mitochondrial membrane potential.

not enhance the promoter activity for Bax induced by $\mathrm{p} 53$ gene transfer (Fig. 4B). Next we examined expressions of other p53-dependent apoptosis-related genes. Expression levels of these genes examined in this study were not enhanced by TSA (Fig. 4C).

Mitochondrial membrane potential. Fig. 5A shows the mitochondrial membrane potential after the treatment with p53 gene transfer and/or TSA. While TSA alone or p53 gene transfer alone slightly decreased the mitochondrial membrane potential, the combination of TSA and p53 gene transfer synergistically decreased it. As shown in Fig. 5B, TSA alone decreased the mitochondrial membrane potential in a dose-dependent manner in the cells without wild-type p53, suggesting that TSA decreased the mitochondrial membrane potential in a p53-independent manner.

\section{Discussion}

Trichostatin A (TSA) has been known to inhibit histone deacetylase activity (10). As histone acetylation mediates transcriptional activation by facilitating the binding of transcription factors to nucleosomal DNA (15), it is reasonable to hypothesize that TSA could enhance p53-dependent transcription of down-stream genes, such as p $21^{\text {Waf1/Cip1 }}$ and Bax, through the enhanced binding of p53 to its binding sites in

the promoter region and then induce apoptosis and cell cycle arrest more efficiently in the combination with p53 gene transfer than in p53 gene transfer alone. In this study, we demonstrated that TSA, which itself induce low levels of apoptosis at the concentrations up to $500 \mathrm{nM}$, synergistically induced apoptosis in MDA-MD-231 cells, in combination with $\mathrm{p} 53$ gene transfer.

The mechanisms by which p53 gene transfer induces apoptosis in the cells with mutated p53 gene are yet to be determined. A number of studies provided evidence that transcriptional activation of p53 was required for apoptosis in some experimental systems $(23,25-28)$. Furthermore, it has been reported that some histone deacethylase inhibitors enhanced the transcriptional activity of p53, resulting in the induction of apoptosis (16). In contrast, there is also strong evidence that p53 can induce apoptosis independently of its transcriptional function (28-32). We clearly demonstrated that p53 gene transfer by itself induced the transcription of $\mathrm{p} 21^{\text {Waf } 1 / \mathrm{Cip} 1}$ and Bax, which were reported to be induced by p53 (33), but did not induce comparable levels of apoptosis with the expression levels of p21 and Bax. This suggested that the transcription of Bax was not sufficient for the induction of apoptosis in some cancer cells. Furthermore, we demonstrated that the combination of p53 gene transfer and TSA reduced mitochondrial membrane potential and the activation of caspase-3. These results suggest that TSA and p53 gene transfer synergistically induced apoptosis at least partially through the synergistic reduction of mitochondrial membrane potential and the activation of caspase cascade. As TSA alone decreased the mitochondrial membrane potential in a p53-independent manner in our study, TSA showed the synergistic effect partially through the direct reduction of mitochondrial membrane potential. A similar result has been reported. Medina et al reported that TSA induced caspase-3 activation and apoptosis of Jurkat and colorectal carcinoma cell lines synergistically through a mitochondrial/cytochrome c-dependent pathway (13). Moreover, it has been reported that p53 translocated to mitochondria decreased mitochondrial membrane potential and activated caspase-3, which is consistent with our results (34-36). Further investigation is required for understanding the mechanisms by which TSA and p53 gene transfer synergistically induced apoptosis in a variety of cancer cell lines; however, it seems likely that death signals triggered by the combination of TSA and p53 gene transfer converged at the mitochondrial membrane potential. It has been demonstrated that histone deacetylate inhibitors induced PIC-3 and Noxa through the acetylation of p53 (37). The difference between our results and theirs cannot be explained presently. We now speculate that the difference might derive from the differences of the cell lines used in the study.

There are several advantages in the combination therapy with histone deacetylase inhibitors and p53 gene transfer for cancers. Our results suggest that the combination induces apoptosis of the cancer cells located even distantly from the injection sites of Ad-p53 and thus receiving low copy numbers of Ad-p53. Furthermore, the combination of p53 gene transfer and histone deacetylase inhibitors may even induce apoptosis of the cancer cells that are resistant to apoptosis induction by p53 gene transfer alone. 


\section{Acknowledgements}

We appreciate Dr H. Ishikura (The First Department of Pathology, Hokkaido University School of Medicine), Dr Y. Tsujimoto (Osaka University Graduate School of Medicine), Dr T. Tokino (Sapporo Medical school), Dr B. Vogelstein (Johns Hopkins University), Dr M. Oren (Weizmann Institute, Israel) for providing us with a pancreatic cancer cell line, a probe for bcl-2, GML, PGI Py-luc and PMO3, respectively. We thank Ms. M. Yanome for assistance in preparing the manuscript. This work was supported in part by grants from the Japanese Ministry of Education, Culture, Sports, Science and Technology.

\section{References}

1. Bartek J, Bartkova J, Vojtesek B, et al: Aberrant expression of the p53 oncoprotein is a common feature of a wide spectrum of human malignancies. Oncogene 6: 1699-1703, 1991.

2. Chen PL, Chen YM, Bookstein R and Lee WH: Genetic mechanisms of tumor suppression by the human p53 gene. Science 250: 1576-1580, 1991

3. Tonish-Rouach E, Resnitzky D, Lotem J, Sachs L, Kimchi A and Oren M: Wild-type p53 induces apoptosis of myeloid leukemic cells that is inhibited by interleukin-6. Nature 352 : 345-347, 1991

4. Roth JA, Nguyen D, Lawrence DD, et al: Retrovirus-mediated wild-type p53 gene transfer to tumors of patients with lung cancer. Nat Med 2: 985-991, 1996.

5. Kock H, Harris MP, Anderson SC, et al: Adenovirus-mediated p53gene transfer suppresses growth of human glioblastoma cells in vitro and in vivo. Int J Cancer 67: 808-815, 1996.

6. Spitz FR, Nguyen D, Skibber JM, Meyn RE, Cristiano RJ and Roth JA: Adenoviral mediated wild-type p53 gene expression sensitizes colorectal cancer cells to ionizing radiation. Clin Cancer Res 2: 1665-1671, 1996.

7. Yang B, Stambrook PJ and Markowitz SD: Wild-type p53 protein potentiates cytotoxicity of therapeutic agents in human colon cancer cells. Clin Cancer Res 2: 1649-1657, 1996.

8. Pirollo KF, Hao Z, Rait A, et al: P53 mediated sensitization of squamous cell carcinoma of the head and neck to radiotherapy. Oncogene 14: 1735-1746, 1997.

9. Ogawa N, Fujiwara T, Kagawa S, et al: Novel combination therapy for human colon cancer with adenovirus-mediated wildtype p53 gene transfer and DNA-damaging chemotherapeutic agent. Int J Cancer 73: 367-370, 1997.

10. Tsuji N, Kobayashi M, Nagashima K, Wakisaka Y and Koizumi K: A new antifungal antibiotic, trichostatin. J Antibiot 29: $1-6,1976$

11. Yoshida M and Beppu T: Reversible arrest of proliferation of rat $3 \mathrm{Y} 1$ fibroblasts in both the $\mathrm{G} 1$ and $\mathrm{G} 2$ phases by trichostatin A. Exp Cell Res 177: 122-131, 1988.

12. McBain JA, Eastman A, Nobel CS and Mueller GC: Apoptotic death in adenocarcinoma cell lines by butyrate and other histone deacetylase inhibitors. BioChem Pharmacol 53: 1357-1368, 1997.

13. Medina V, Edmonds B, Young GP, James R, Appleton S and Zalewski PD: Induction of caspase- 3 protease activity and apoptosis by butyrate and trichostatin A (inhibitors of histone deacetylase): dependence on protein synthesis and synergy with a mitochondrial/cytochrome c-dependent pathway. Cancer Res 57: 3697-3707, 1997.

14. Struhl K: Histone acetylation and transcriptional regulatory mechanisms. Genes Dev 12: 599-606, 1998.
15. Sambucetti LC, Fischer DD, Zabludoff S, et al: Histone deacetylase inhibition selectively alters the activity and expression of cell cycle proteins leading to specific chromatin acetylation and antiproliferative effects. J Biol Chem 274: 34940-34947, 1999.

16. Takimoto R, Kato J, Terui T, et al: Augmentation of antitumor effects of p53 gene therapy by combination with HDAC inhibitor. Cancer Biol Ther 4: 421-428, 2005.

17. Katayose D, Wersto R, Cowan KH and Seth P: Effects of a recombinant adenovirus expressing WAF1/Cip1 on cell growth, cell cycle, and apoptosis. Cell Growth Differ 6: 1207-1212, 1995.

18. Macho A, Decaudin D, Castedo M, Hirsch T, Susin SA and Zamzami N: Chloromethyl-X-Rosamine is an aldehyde-fixable potential sensitive fluorochrome for the detection of early apoptosis. Cytometry 25: 333-340, 1996.

19. Choi S, Kobayashi M, Wang J, et al: Activated leukocyte cell adhesion molecule (ALCAM) and annexin II are involved in the metastatic progression of tumor cells after chemotherapy with adriamycin. Clin Exp Metastasis 18: 45-50, 2000.

20. Kimura Y, Furuhata T, Shiratuchi T, Nishimori H, Hirata K and Nakamura Y: GML sensitizes cancer cells to Taxol by induction of apoptosis. Oncogene 15: 1369-1374, 1997.

21. Oda K, Arakawa H, Tanaka T, et al: p53AIP1, a potential mediator of p53-dependent apoptosis, and its regulation by Ser-46-phosphorylated p53. Cell 102: 849-862, 2000.

22. Kostic C and Shaw PH: Isolation of sixteen novel p53 response genes. Oncogene 19: 3978-3987, 2000.

23. Attardi LD, Reczek EE, Cosmas C, et al: PERP, an apoptosisassociated target of p53, is a novel member of the PMP-22/gas3 family. Genes Dev 14: 704-718, 2000.

24. Wang J, Kobayashi M, Sakurada K, Imamura M, Moriuchi T and Hosokawa M: Possible roles of adult T-cell leukemia-derived factor/thioredoxin I the drug resistance of ATL to Adriamycin. Blood 89: 2480-2487, 1997.

25. Sabbatini P, Lin J, Levine AJ and White E: Essential role for p53-mediated transcription in E1A-induced apoptosis. Genes Dev 9: 2184-2192, 1995.

26. Miyashita T and Reed JC: Tumor suppressor p53 is a direct transcriptional activator of the human bax gene. Cell 80: 293-299, 1995.

27. Wu GS, Burns TF, McDonald ER III, et al: KILLER/DR5 is a DNA damage-inducible p53-regulated death receptor gene. Nat Genet 17: 141-143, 1997.

28. Polyak K, Xia Y, Zweier JL, Kinzler KW and Vogelstein B: A model for p53-induced apoptosis. Nature 389: 300-305, 1997.

29. Caelles C, Helmberg A and Karin M: p53-dependent apoptosis in the absence of transcriptional activation of p53-target genes. Nature 370: 220-223, 1994.

30. Haupt Y, Rowan S, Shaulian E, Vousden KH and Oren M: Induction of apoptosis in HeLa cells by trans-activationdeficient p53. Genes Dev 9: 2170-2183, 1995.

31. Rowan S, Ludwig RL, Haupt Y, et al: Specific loss of apoptotic but not cell-cycle arrest function in a human tumor derived p53 mutant. EMBO J 15: 827-838, 1996

32. Ding HF, Lin YL, McGill G, et al: Essential role for caspase-8 in transcription-independent apoptosis triggered by p53. J Biol Chem 275: 38905-38911, 2000.

33. El-Deiry WS: Regulation of p53 downstream genes. Semin Cancer Biol 8: 345-357, 1998.

34. Marchenko ND, Zaika A and Moll UM: Death signal-induced localization of p53 protein to mitochondria. J Biol Chem 275: 16202-16212, 2000 .

35. Moll UM and Zaika A: Nuclear and mitochondrial apoptotic pathways of p53. FEBS Lett 493: 65-69, 2001.

36. Wolff S, Erster S, Palacios G and Moll UM: p53's mitochondrial translocation and MOMP action is independent of Puma and Bax and severely disrupts mitochondrial membrane integrity. Cell Res 18: 733-744, 2008.

37. Terui T, Murakami K, Takimoto R, et al: Induction of PIG3 and NOXA through acetylation of p53 at 320 and 373 lysine residues as a mechanism for apoptotic cell death by histone deacetylase inhibitors. Cancer Res 63: 8948-8954, 2003. 